\title{
An Investigation of Economic Sanctions and Its Implications for
}

\section{Africa}

Frederick Appiah Afriyie ${ }^{1} \&$ Jisong Jian $^{2}$

\author{
${ }^{1}$ Zhongnan University of Economics and Law, Wuhan, China \\ ${ }^{2}$ Law School, Zhongnan University of Economics and Law, Wuhan, China \\ Correspondence: Frederick Appiah Afriyie, Zhongnan University of Economics and Law, Wuhan, China. E-mail: \\ frederickappiahafriyie@qq.com
}

Received: February 20, 2018

Accepted: March 19, $2018 \quad$ Online Published: August 30, 2018

doi:10.5539/jpl.v11n3p74

URL: https://doi.org/10.5539/jpl.v11n3p74

\begin{abstract}
Economic sanctions are not only applied to countries in Africa by the United Nations (UN), the European Union (EU) and the United States (US) but also by the African Union (AU) and the Economic Community of West African States (ECOWAS) as well. The African continent is considered to be the most affected in terms of the influences of more economic sanctions from the UN, EU, and the U.S than any other continent across the globe and these sanctions normally comes into force as a result of conflicts, civil wars and also unconstitutional overthrow of a constitutionally elected government. Also these sanctions come to serve as a punishment and a deterrent to those who deviate from or go against internationally agreed laws.

Undeniably, in recent years economic sanctions have become more effective and an efficient known foreign policy tool used as the number one alternative to halt wars or military takeovers.

Despite economic sanctions being widely accepted by the international community as the most effective panacea and also a preferred choice, when it is imposed on a state, it has serious repercussions on the innocent citizens while the initiators or the main officials in various positions for whom these sanctions were intended for are always left off the hook.

This paper therefore investigates the merits and the demerits that are associated with economic sanctions both within some countries on the African continent and the non-African continent. In addition, we will elaborate on the implications of such sanctions relative to the Africa Continent. The paper is divided into four sections. The first section of this paper elaborates on the introduction, the importance of economic sanctions and the types of sanctions. The second section deals with the definition of economic sanction, explains the sanction process at EU, $\mathrm{AU}, \mathrm{UN}$ and the US and the final part looks at both the positive and negative effects of economic sanctions.
\end{abstract}

Keywords: economic pressure, non-economic pressure, punitive sanctions, humanitarian

\section{Introduction}

Among all the continents that exist, Africa has been the target of more economic sanctions from the United Nations (UN), the European Union (EU), and individual states specifically United States (U.S) than any other continent on the globe. (Lyman, 2016, June 8).

Currently, economic sanctions have become the most effective and a popular foreign policy tool that the international community cannot relegate to the background. The UN body has been set up purposely to maintain international peace and security. Constitutionally, the powers are derived from Chapter V of the UN Charter and the United Nations Security Council (UNSC) is delegated with the authority to respond to any threat or breach to international peace and security or any acts of aggression. The main provisions for authorizing economic sanctions (and military action) are found in Chapter VII of UN Charter (articles 39 and 41) (Gorlee, 2017).

For the first forty-five (45) years since the inception of the UN Security Council, it has only imposed sanctions on two regimes and both outcomes were mainly considered productive. The sanctions mostly targeted southern Rhodesia (now named Zimbabwe) and South Africa, both white-only settler regimes. In the year 1966, mandatory sanctions were first imposed by the Security Council due to the outcome of the white minority's unilateral declaration of independence as well as targeted sanctions on South Africa in a response to its apartheid system and its regional military aggression in pursuit of a nuclear weapons capability (Security Council report, 


\section{3 \& Paul, Global Policy Forum).}

On the other hand, after the cold war formally came to a halt in December 1991 (Wikipedia, 2011, December 11), the African continent has consistently recorded the topmost sanctions, not only imposed by the UN, EU, and the US, but also by other recognized international bodies set up within the African continent such as the Africa Union and the Economic Community of West African States. A lot of countries on the African continent and few non-African countries that have suffered UN sanctions includes Somalia, Ethiopia, Eritrea, Rwanda from the eastern and Libya, Liberia, Cote D'Ivoire, Sierra Leone, Haiti, Yugoslavia, Iraq and North Korea.

The European Union is also another body that has been given the mandate to impose economic sanctions on its member states and also on states outside its boundaries. At present, EU sanctions to a certain extent have played a very paramount role in Africa and their goal has been on promoting human rights and support for democracy. There are roughly about 35 countries, terrorist organizations, and regimes experiencing EU sanctions.

AU constitutes Act Article 23 and 30 according to the African Union empowers the Union to carry out sanctions on it's member states and one known case was when Mali military leaders and armed rebels unlawfully seized power in the northern part of the country from the constitutionally elected government and as a result of this, sanctions were imposed on the military leaders and the armed rebels by the Union.

Finally, the United States is the only country on the globe that has exercised economic sanctions more than any other nation and mostly these sanctions are targeted at terrorist groups, human rights abusers, authoritarian or dictatorship regimes and also those engaging in nuclear proliferation. In addition, the Office of Foreign Assets Control (OFAC) is that branch of the US Department of the Treasury that fabricates and enforces the economic sanctions imposed by the United States.

\subsection{History of Economic Sanctions}

To commence with, economic sanctions have been used both by countries of the $20^{\text {th }}$ century up to this present-day. According to Gary Hufbauer, Jeffery Schott, and Kimberly Elliot (hereafter HSE), before the emergence of the first world war 1, there were at least 13 well known economic sanction cases that existed and during the early 432BC, the most famous economic sanctions case occurred, and this happened when Pericles issued the "Megaran decree" restricting the entry of Megara's products into Athenian markets and the subsequent denial of responsibility to lift the Athenian boycott of Magara trigger the Peloponnesian war (Thucydides, 1972).

Even though international bodies and Countries have exercised economic sanctions in one way or the other, it can be said that the U.S is one country that has unilaterally used it with or without assistance from other nations and no country across the globe can be compared to them in terms of its application on others. They have used it as a form of punishment on those who do not comply with the globally agreed laws and the U.S also considers it as a more powerful foreign policy tool to keep the world safe. This evidence was confirmed by Gary Clyde Hubauer and colleagues (2007) in their extensive study of over two hundred episodes of sanctions over the last century draw and they concluded that the United States have exercised economic sanctions far more than any other nation on the globe. From the time period between 1914 and 1968, there has been a total of 165 cases of economic sanctions initiated and out of these total, 115 cases included the United States, and of which 68 cases were solely U.S initiatives according to HSE (Hubauer, 1999).

\subsubsection{Methodology of the Study}

In order to completely fathom the positive and negative implications of economic sanctions both within the African continent and non-African continent, the research methodology adopted was conducted through a literary-based as well as a review of literature from existing researchers on economic sanctions, internet sources, books and reports on sanctions from international bodies was also incorporated. The study did not make use of any primary source of data. The data obtained were qualitatively analyzed in an objective manner so as to outline the positive and negative implications. As noted by (Burnham et al.., 2004, cited Morris 2009\& Ayangbah \& Sun 2016), the extensive range of data from distinct sources produces qualitative analysis and this allow a broad thorough analyses of a phenomenon. It offers a detailed and an in-depth elucidation of the subject under investigation in a more comprehensive manner.

\section{Definition of Economic Sanctions}

Economic sanctions are the deliberate withdrawal of customary trade or financial relations (Hufbauer et al., 2007), ordered by a state, supra-national or international governmental organization (the 'sender') from any state, sub-state group, organization or individual (the 'target') in response to the political behavior of that target. According to Macallee N. Goldman (2016), when scholars talk about economic sanctions, it refers to comprehensive sanctions. The term "economic sanction" merely seeks to act as a broad category which 
encompasses all sanction types.

The following terms are considered paramount to any study of the subject: Firstly, economic sanctions may include the withdrawal of customary trade or financial relations in whole or in part.

Trade may perhaps be limited in its totality by rejecting all imports and exports. If all imports and exports are denied, then the sanctions, are known as 'comprehensive' sanctions.

The sender is the key author of the sanctions. It involves more than one state. Additional, one country usually (sender) takes the central role and commonly brings others into the fold either by unilaterally ordered by one state acting alone or ordered multilaterally through an international organization such as the United Nations, regional organizations and the European Union. (Hufbauer, Schott, and Elliott, 1986)

Target is the instant object of the sanctions episode and generally, which is exclusively single country. However, economic sanctions may be applicable to two or more countries. (Hufbauer, Schott, and Elliott 1986).

\subsection{The Importance's of Economic Sanctions}

The importance of economic sanction can be used to address the emerging threat to international peace and security which includes, firstly dissuading other countries from choosing an unlawful course of action. Secondly, Sanctions can be used to avert or halt the way to war. Thirdly, it can either be used to persuade a transformation in policy or to bring about a regime modification and lastly, it can be used to deter and punish those who break or go contrary to international norms.

\section{Types of Economic Sanctions}

Economic sanctions can be grouped into financial sanctions, trade sanctions, and smart sanctions or targeted sanctions

\subsection{Trade Sanction}

Trade sanctions are a restriction placed on either a country`s import or export and this is usually enforced by the international community if they seek to effect political changes. South Africa, Zimbabwe (Rhodesia) and Iraq are concrete evidences of countries that have suffered trade sanctions in the hands of the international community. (Gono, 2006, January 24)

\subsubsection{Financial Sanctions}

Financial sanctions are restrictive measures that obstruct financial flows such as aid, short and long-term loans, as a result reducing foreign exchange flows to the target. (Gono, 2006). A well-known case was when financial sanctions were imposed on the two sons of the Lord's Resistance Army (LRA) rebel leader Joseph Kony by the Treasury of US and this sanction involved freezing all assets belonging to the two sons in the US (VOA News, 2016, August 23).

\subsection{2 "Targeted Sanction "or "Smart Sanction"}

"Targeted Sanctions" or "Smart sanctions" is intended to concentrate on certain groups or individuals in the target country with the aim of having a direct impact on these groups as stated by (Hufbauer and Oegg 2000). The case of Pinochet and Bosnian war crimes trial has made the concept of targeted sanctions clearer and meaningful.

\section{Ways in Which Economic Sanctions Are Implemented}

According to Maurits Gorlee, economic sanctions can be implemented in three different ways unilateral sanction, multilateral sanctions or universal supranational sanctions.

\subsection{Unilateral Sanctions}

Unilateral sanctions are when one state takes economic measures to force a change in the policy of another state without the authorization from the United Nations Security Council.

\subsubsection{Multilateral Sanctions}

Multilateral sanctions include a group of countries taking part in the sanctions with or without the authorization from the United Nations Security Council with the aim of leading to a total block out.

\subsubsection{Universal Supranational Sanctions}

Universal supranational sanctions occur when the international community has been granted full authorization from the United Nations Security Council. 


\section{Sanctions Procedure at the United Nations (UN), European Union (EU), Africa Union (AU) and United States (US).}

\subsection{Sanction Procedure at UN}

The UN body is set up with the main objective of managing the crisis that threatens global peace and security. The UN foundation for Sanctions under international law derived from Chapter VII of the UN Charter, and particularly, Article 41, which authorizes the Security Council to impose sanctions states that "the security council may call on member states to apply measures not involving the use of armed force to give effects to its decision". These mechanisms are sanctions and they are there to empower international law. Sanctions have the ability to be a paramount and effective tool and have yielded positively for some in terms of results according to (Paul, 1997 \& Global Policy Forum).Whenever a country is imposed with economic sanctions, the Security Council establishes a sanctioning committee to monitor and supervise the fifteen (15)-member body with the Security Council by majority vote. However, any negative cast vote of the five (5) permanent members including the US, China, Russia, Britain, and France on any resolution or decision would not be approved. All the five predominant members have their right of veto at some point or another.

\subsubsection{Sanction Procedure at AU}

The Africa Union is a body set up by the 55 states on the continent. It has the power to enforce sanctions on any member states that deviates from the agreed laws. Constitutionally, the union derives its powers from African Union Constitute Act of article 23 and there are three separate provisions in the Constitute Act that deals with sanctions. The first provision is Article 23(1) which empowers the Assembly to determine the sanctions to be imposed on any member state defaulting in the payment of its contributions to the Union budget (AU Constitute Act, Article 23 (1). The Second provision is article 23(2) which specifies that any failure to comply with AU decisions and policies may be subjected to further sanctions, such as the denial of transport and communications links with fellow members, and this on the other hand empowers the Assembly to determine the imposition of any other measures of a political and economic nature (AU Constitute Act, Article 23(2) Finally, Governments which shall come to power through unconstitutional means shall not be allowed to participate in the activities of the Union. (AU Constitute Act 30).

\subsubsection{Sanction Procedure at EU}

The EU is a body set up as a political and an economic union consisting of a 28 member states. The council of the EU imposes EU economic sanctions through a Common Foreign and Security Policy (CFSP) decision adopted by the member states consensus decision. EU sanctions transforms into two forms. The Chapter VII of the UN charter explicitly elucidates that EU member states must by obligation enforce in the EU law the United Nations (UN) Security Council virtue of settlement or resolution. The Second is the free sanctions, which the EU upholds in the absence of external factors or in accumulation to the UN Sanctions. Conclusively, EU sanctions should give preference or attention to the right of the individual and basic emancipation, in specific due method and the franchise to an effective panacea, all of which are fortified by the EU Charter of fundamental rights under EU law. When EU sanctions are enforced, the EU rightfully bond the EU institutions and member states. (Article 51(1) of EU Charter of Fundamental Rights.

\subsubsection{Sanction Procedure by the US.}

The executive order is responsible for the release of sanctions and the President of the United States makes it valid through his signature. The foreign Asset Control as a subsidiary division of the Treasury Department has been delegated with power to enforce these control through national emergency powers most explicitly the legislation and the executive order. According to U.S foreign policy and national security goals, massive of economic trade function, foreign trade function and national security goals are the mainstream under the enforcement of OFAC. (US Department of the Treasury, 2018). In addition, departments including departments of state and the departments of commerce also play an integral role. The U.S sanctions are normally enforced against states that support terrorism, those involve in proliferation of nuclear, biological and chemical weapons and those that engage in the abuse of political and civil rights of others. The Majority of the U.S sanctions are taken unilaterally without the approval from the UN but sometimes they try to seek coordination with other states. The OFAC currently manages 29 programs sanctions in force and these sanctions run from a fathomable embargo in the case of North Korea to specific sanctions on specific industrial sectors or region within a country and this is in line with the case of Ukraine-Russia sanctions.

\section{General Overview of Economic Sanction in Africa}

There is no doubt from the archives of history that the Africa continent has been the largest recipient of 
economic sanctions more than any other continent on the globe and these sanctions against the continent were not only from the UN, EU, and the U.S but also involved AU and the ECOWAS. All these sanctions emerged an as the result of numerous conflicts and civil wars that have engulfed the continent through unconstitutional overthrow of constitutionally elected government and most of the UN, US, and the EU sanctions have been targeted at the Africa continents due to these activities. Historically on the continent of Africa, the only two inter-wars governments were designed among Eritrea and Somalia and also Ethiopia and Eritrea.

African Union also have imposed sanctions on its member states. The main aim of the AU is to aid in the prevention, management and the settlement of crisis on the continent. Any member states that goes contrary to the said norms or rules of the union is subjected to sanctions from the union. The African Union have applied 15 sanctions regimes against twelve states since the year 2001. Some of these countries comprises of Central African Republic, Comoros, Côte d'Ivoire, Egypt, Guinea-Bissau Guinea-Conakry, Libya, Madagascar, Mali, Mauritania, Niger and Togo. All these sanctions were as a result of an unconstitutional change in government.

The Economic Community of West Africa states which consist of 15 member states has been one body that has been very effective in imposing sanctions on its member states both in the past and the present. Most recent one was sanctions against Mali in 2012 and Cote d'Ivoire in 2010 and past ones that have equally experienced such sanctions include countries such Togo, Sierra Leone, Niger, Guinea- Bissau and Guinea Conakry. These occurrences were as a result of an unconstitutional change in government as reported by (Charron \& Portela, 2015).

\section{Analysis of the Positive and Negatives implications of Economic Sanctions on Africa by the Use of Sanction Mechanisms}

The outcome of any form of economic sanctions is often harmful to the sanctioned countries. Bureaucrats who have been part of the process in imposing sanctions acknowledge the fact that sanctions could have an adverse effect on the entire general public. In an editorial in the Annals of Internal Medicine, former U.S Secretary of States, Madeleine Albright, specified that ;When the United States or the United Nations enforces sanctions against a regime, it doesn't aim to create pointless adversities for innocent people, particularly children, and infants. Good intentions, nevertheless, don't automatically interpret into good results (Albright 2000).

Inferring from the above statement, it can be realized that no matter how sanctions are imposed there will always be both positive and negative repercussion on the target individual or the Country. Below are some of the effects of economic sanctions on pretentious countries both within the continent of Africa and outside the African continent using the five mechanisms such as economic pressure, non-economic pressure, denial of resources, sending of messages and punitive sanctions (Ellis, 2013).

\subsection{Economic Pressure}

Firstly, economic pressure in the form of assets freezing, travels bans, arms embargoes, bans on the country timber and diamond that was initiated against Charles Taylor during the Liberian civil war helped in the collapse of Taylor 's regime. Even though other domestic and international factors also played a role, pressure from economic sanctions was considered to have played the central role in bringing lasting peace and security to the country. Master (2017, August, 7)

Secondly, similar pressure from economic sanctions assisted in the downfall of the regime of president Gbagbo of Cote d'Ivoire and this brought peace to the country. The pressures were mounted when he refused to accept the verdict of the people after losing the election to the opposition leader and this ultimately led to violence, loss of lives, as well as the breakdown of the country's economy but peace was able to prevail again with the aid of pressure imposed through economic sanctions.

\subsubsection{Economic Pressure and Non-Economic Pressure}

Thirdly, the strong outcome of economic and non-economic pressure from the international community against the regime of the apartheid system aided in isolating South Africa from the rest of the world. The pressure from both isolation and South African business community persuaded the government under the presidency of F.W de Klerk to negotiate the peaceful and orderly transfer of power to the ANC through free voting in which entire people of all races took part on equal terms (House of Lords $2^{\text {nd }}$ report of session, 2006-07)

\subsubsection{Economic Pressure and Denial of Resources}

Fourthly, the use of economic pressure and the denial of resources in the form of aid sanctions against Malawi by the United States and other nations enabled Malawi to modify its democratic standards and human rights situation in that country. Since Malawi was largely dependent on aid, aid sanction ushered the country into 
democratization and this as a result aided the country to strengthen the demands of domestic opposition forces and the resultant effect was referendum and multi-party democracy been implemented.(Taylor,2014 April 28)

\subsubsection{Economic Pressure and Sending Message}

Furthermore, the economic sanctions imposed by South Africa on Lesotho aided in mounting pressure on Lesotho to make the deportation of the 60 ANC South African refugees back with links to the African National Congress and also pressure from economic sanctions enforced by the US against EI Salvador assisted in obstructing him from releasing the killers of US citizens. (Taylor, 2014, April 28)

Additional pressures from economic sanctions on Yugoslavia under the regime of President Milosevic brought him to the peace table and the outcome of these economic pressures persuaded the then president Slobodan Milosevic to bring the war to a halt for the greater good of Serbian citizens. It also led to the signing of Dayton peace accord in the late 1995 and without sanctions being a powerful tool in place, it would have seem very unlikely that Serbia would have considered the terms of Dayton accord. (Clinton, 1995).

\subsubsection{Message Sending}

Finally, the threatening messages of economic sanctions sent by the US and EU against Guatemala president Jorge Serrano who dissolved congress and wanted to rule by decree forced the business owners to coerce president Serrano out of power and installed a new Ramiro de Leon Carpio as the country new president (Taylor, 2014 )

\section{Negative Implications of Economic Sanctions}

\subsection{Punitive Sanctions}

The consequence of economic sanctions has caused severe harm and suffering to about 13 million Zimbabweans. It was even estimated that unemployment rate in 2009 was near to $95 \%$ which made it the highest in the world and poverty also skyrocketed to 75 percent. This attracted punitive sanctions from the international community as a result of controversial land reform program initiated in the year 2000 by the government of Mugabe's that led to the squatters invading and seizing the majority of white-owned farms for the settlement of poor black farmers. These seizures were not peaceful because the effect was violent and multiple murder of white farmers (Gaffey, 2016)

In addition, the negative perception associated with economic sanctions has adversely impacted foreign direct investment to the affected countries. It has also created a bad reputation for the affected countries and that has also driven investors away from investing in the country. This is currently happening in Zimbabwe and causing harm to the population.

Furthermore, the population of Sudan was inflicted with harms and suffered international condemnation through economic sanctions imposed on them by the US. These sanctions have fabricated a deep gap in income distribution within the society of Sudan and the provinces of the country as well. These activities further encouraged the emergence of a shadow economy, which was likely exposed to a variety of illegal practices such smuggling, money laundering, tax invasion, arms trafficking, and corruption. Also, the punitive sanctions instigated by UNSC on Iraq caused much loss of lives. The consequences of the sanctions were catastrophic to the population, especially children. As stated by the researchers, the estimated death was between 670,000 and 880,000 and children under five were the most affected victims as an outcome of the impoverished conditions triggered by the economic sanctions. (Cashen, 2017 April 20)

Finally, economic sanctions imposed on North Korea both in the past and present have had a severe impact on the population as it is estimated that more than 70 percent of the populace remains food insecure, with just 20 percent of the nation's landscape serving as farmable land. Additionally, this punitive measures against the country has caused the relocation of some 300,000 North Koreans into eastern China in recent years in order to escape all these prolong years of drought, hardship, and famine. (Cashen, 2017). In addition, sanctions from the US and EU on Russia in 2014 till date by annexation Crimea have caused the relationship between US and EU to the lowest freezing point since the end of the cold war and this, as a result has hindered the development of the Russian economy and its negative impact also is being felt by the population as well (Wang, 2015).

\section{Conclusion}

Deducing from the study, it can be recognized that economic sanctions imposed on Africa continent is not only from the United Nations, the European Union and the United States but also from the African Union and the Economic Community of West African States as well. The African continent has been the most receiving end of economic sanctions and the cause of these sanctions is as a result of conflicts, civil wars, overthrowing of 
constitutionally elected governments and also deviating from internationally agreed laws. Undeniably, economic sanctions have become universally acceptable foreign policy tools in international affairs and are also considered to be non-military alternatives to wars involving less risk and cost, whether it is human, financial or moral.

Despite being considered by many intellectuals as the best tool available at the moment, it can work effectively and efficiently if fully supported by the international community.

From the writers'perspective, economic sanctions have been helpful in maintaining global peace and security and even though there are some merits and demerits associated with economic sanctions, the conclusion that can be drawn is that, it has helped by bringing an end to conflicts and wars in many places across the globe especially on the continent of Africa as well as the collapsed of many unconstitutional regimes. Also sanctions have restrained recalcitrant leaders from further causing harm and atrocities to their citizens.

In our best and realistic opinion, we think the positive effects of economic sanctions far outweighs the negative effects and therefore, it has reliably made the continent more peaceful and stable as compared to the past.

\section{References}

Adam, T. (2014, April 28). 13 times that economic sanctions really worked. Retrieved from https://www.washingtonpost.com/news/worldviews/wp/2014/04/28/13-times-that-economic-sanctions-reall y-worked/?utm_term=.ee232d77b1f2

Albright, M. K. (2000). Economic Sanctions and Public Health: A View from the Department of State. Annals of Internal Medicine, 132(2), 155-157. https://doi.org/10.7326/0003-4819-132-2-200001180-00012

Barbara, C. (1995, Dec 11). Iraq Sanctions Kill Children, U.N. Reports.

Bill Clinton. (1995). Dayton Accords International Agreement. Retrieved from https://www.britannica.com/event/Dayton-Accords

Cable News Network (CNN) Library. (2017, May 4). Retrieved from www.cnn.com/2013/09/03/world/united-nations-security-council-fast-facts/index.html

Conor, G. (2016). Zimbabwe president Robert Mugabe: we will not prosecute killers of white farmers.

Denis, M. (2016, March 15). Sanctions and Embargoes: How are they different?

Dina Esfandiary. (2013, December). Assessing the European Union`s sanctions policy: Iran as a case study.

Elin Hellquist. (2014, January). Regional Organizations and Sanctions Against Members Explaining the Different Trajectories of the African Union, the League of Arab States, and the Association of Southeast Asian Nations.

Elizabeth, E. (2013). The Ethics of Economic Sanctions.

Emily, C. (2017, April 20). The impact of economic sanctions.

EMPOPS. (2011, June 21). Literature review on the effect of targeted sanctions: implications for human rights and humanitarian services delivery in Libya.

Gary Clyde Hufbauer and Barbara Oegg. (2000, February 23). Targeted Sanctions: A Policy Alternative? Retrieved from https://piie.com/commentary/speeches-papers/targeted-sanctions-policy-alternative

Gary Clyde Hufbauer. (1999, April 12-18). “Trade as a Weapon,” paper for the Fred J. Hansen Institute for World Peace, San Diego State University, and World Peace. Retrieved July 25, 2000, from http://www.iie.com/TESTMONY/gch9.htm

Gary, C. H., Jeffery, J. S., \& Kimberly, A. E. (1986). Economic in Support of foreign policy Goals.

Gideon Gono. (2006, Jan 24). Impact of economic sanctions-reserve bank of Zimbabwe.

Global Policy $\quad$ Forum (GPF). $\quad$ (n.d.). $\quad$ Retrieved from https://www.globalpolicy.org/security-council/index-of-countries-on-the-security-council-agenda/angola.ht $\mathrm{ml}$

Hufbauer, G., Jeffrey, S., \& Kimberly, A. E. (2007). Economic Sanctions Reconsidered (3rd ed.).

Ioana, M. P. (2010, July). The Humanitarian Impact of Economic Sanctions.

Jonathan, M. (2017, August 7). What are Economic Sanctions.

Kenneth, R. (2015, January 5). Economic sanctions have a long and chequered history.

Kimberly, A. E. (1999). Analyzing the effects of targeted Financial Sanctions. 
Konstantinos, M. (2011, October 11-13). The sanctioning system of the AU: part success, part failure?

Macallee, N. G. (2011). An ethics of economic sanctions.

Maurits, G. (2017). Retrieved from http://mauritsgorlee.com/economic-sanctions/types-economic-sanctions/

Morris, Z. S. (2009). The truth about interviewing elites. Politics, 29(3), 209-217. https://doi.org/10.1111/j.1467-9256.2009.01357.x

Princeton, N. L. (2016, June 8). U.S. Sanctions Policy in Sub-Saharan Africa: Testimony before the Senate Foreign Relations Subcommittee on Africa and Global Health Policy.

Priyanka, P. (2015, July 20). 6 Countries That Are Currently Under Economic Sanctions.

Raúl, R. (2016, May 2). U.S. Economic Sanctions on Cuba: An International Ethics Perspective.

Shirley, A., \& Liu, S. (2016). Using Arbitration for Resolving Foreign Investment Disputes: A Comparative study of laws on Arbitration in Ghana and China. Journal of Politics and Law.

Thucydides. (1972). History of the Peloponnesian War. translated by Rex Warner.

$$
\text { UN News. (2003, } \quad \text { May } 6) \text { from }
$$
http://www.un.org/apps/news/story.asp?NewsID=6976\&Cr=\#.WmVYir9zKBs

US Department of the Treasury. (2018). Retrieved from https://www.treasury.gov/about/organizational-structure/offices/Pages/Office-of-Foreign-Assets-Control.asp $\mathrm{x}$

VOANEWS. $\quad$ (2016, August 23$). \quad$ Retrieved from https://www.voanews.com/a/us-imposes-economic-sanctions-sons-of-african-rebel-leader-joseph-kony/347 7990.html

Wan, W. (2015). the impact of western sanctions on Russia in the Ukraine Crisis. Journal of Politics and Law.

Wikipedia. (2017, December 11). Retrieved from https://en.wikipedia.org/wiki/Cold_War_(1985-1991)

\section{Copyrights}

Copyright for this article is retained by the author(s), with first publication rights granted to the journal.

This is an open-access article distributed under the terms and conditions of the Creative Commons Attribution license (http://creativecommons.org/licenses/by/4.0/). 